\title{
Landmarks for diagnosis and surgery in abnormal ventriculo-arterial connections with usual arrangement
}

\author{
A Capuani", N Soulé, M Meot, B Aupy, MC Vaillant, J Poinsot, B Lefort, A Chantepie, P Marticho, P Neville \\ From 23rd World Congress of the World Society of Cardio-Thoracic Surgeons \\ Split, Croatia. 12-15 September 2013
}

\section{Background}

The term "malposition of great arteries" is commonly used for diagnosis and surgery in abnormal ventriculoarterial connections with usual arrangement and two well developed ventricles. In these abnormalities the variability of the arterial relationships is considerable and all relationships from normal to side by side to antero posterior have to be expected.

Can we find other anatomical landmarks for the diagnosis and the subsequent corrective surgery?

\section{Methods}

We reviewed the specimens previously published and observations collected in three different institutions.

\section{Results}

There is a gradual transition from Tetralogy of Fallot to double outlet right ventricle with subaortic ventricular septal defect to Taussig-Bing hearts to transposition of great arteries. In this transition the normal aortic-mitral continuity is progressively lost with gradual development of pulmonary- mitral continuity.

The key features determining the sequence of these abnormalities are the relationships between the outlet septum and the ventricular musculature. We may describe and group these malformations in function of the anticlockwise rotation of the outlet septum and the septomarginal trabeculation.

\section{Conclusion}

The term "malposition of great arteries" is a generic term which is of little help for diagnosis and surgery, therefore, it should be avoided.

* Correspondence: capathos@hotmail.com

Ped. Cardiology, Clocheville Hospital, CHRU Tours, France
We recommend a detailed description of the outlet septum and the septomarginal trabeculation in relation to the VSD. Careful attention to these structures dictates the diagnosis and the best surgical approach.

\section{Acknowledgements}

We are grateful to Prof. Robert $\mathrm{H}$. Anderson for the invaluable help and discussions during this study.

Published: 11 September 2013

\section{doi:10.1186/1749-8090-8-S1-0251}

Cite this article as: Capuani et al.: Landmarks for diagnosis and surgery in abnormal ventriculo-arterial connections with usual arrangement. Journal of Cardiothoracic Surgery 2013 8(Suppl 1):0251.

Submit your next manuscript to BioMed Central and take full advantage of:

- Convenient online submission

- Thorough peer review

- No space constraints or color figure charges

- Immediate publication on acceptance

- Inclusion in PubMed, CAS, Scopus and Google Scholar

- Research which is freely available for redistribution

\section{C) Bïomed Central}

@ 2013 Capuani et al; licensee BioMed Central Ltd. This is an Open Access article distributed under the terms of the Creative Commons Attribution License (http://creativecommons.org/licenses/by/2.0), which permits unrestricted use, distribution, and reproduction in any medium, provided the original work is properly cited. 